\title{
Notas
}

\author{
JAVIER BERISTAIN
}

\section{Antonio Carrillo Flores}

DESDE JULIO DE 1971 hasta octubre de 1972 Antonio Carrillo Flores fue rector del Instituto Tecnológico Autónomo de México. Aunque su rectorado fue breve, su impacto fue trascendental y definitivo. Que un hombre de su recia personalidad y brillante trayectoria profesional se haya ocupado de dirigir nuestros destinos há señalado un hito en la historia todavía joven de nuestra institución.

Al creer en el Instituto Antonio Carrillo Flores inspiró en sus integrantes la confianza necesaria para avanzar con paso firme hacia sus metas de excelencia académica y servicio al país.

En el ITAM, al igual que en tantas otras instituciones y obras, Don Antonio Carrillo Flores demostró los atributos que le ganaron la admiración y el respeto sinceros de quienes tuvimos la oportunidad de colaborar con él, y de muy diversos grupos sociales y políticos.

Fueron muchas y notables las cualidades de Don Antonio: gran sentido de la amistad, la lealtad y la integridad; humor y bonhomía; mente aguda, perspicaz y ágil; a mplia base de conocimientos adquiridos por el estudio, la conversación y la experiencia; hombre de palabra pero más hombre de acción; maestro pero sobre todọ político; abogado y legislador, banquero y financiero, canciller y embajador; servidor público siempre. Fue un gran mexicano que supo vivir a la altura de su tiempo.

La historia del México contemporáneo no puede escribirse sin las referencias constantes a la persona y la obra de Carrillo Flores. Don Antonio participó activamente en la construcción de las principales instituciones financieras de este país, y en la definición y defensa de mejores principios y normas de actuación internacional, entre otras muchas tareas.

Inició su vida de servicio como abogado. Muy pronto, sin embargo, comenzó una distinguida carrera en el sector financiero 
público. Como director de la Nacional Financiera impulsó obras de infraestructura industrial sin las cuales el extraordinario progreso de los años cincuenta y sesenta no habría sido posible. Al llegar a la Secretaría de Hacienda y Crédito Público, en el sexenio 19521958 , enfrentó con éxito la última fluctuación económica previa a los años del desarrollo estabilizador.

El programa que Antonio Carrillo Flores había creado para desarrollar económicamente a México contenía dos elementos principales: la industrialización acelerada a cargo, preferentemente, de la iniciativa privada, y la estabilidad macroeconómica mediante el uso activo por el gobierno de todos los instrumentos de las políticas fiscal, monetaria, crediticia y de cambios.

Antonio Carrillo Flores dirigió la política económica para evitar que el gasto público y el crédito provocaran aumentos redundantes en la oferta de dinero. Aunque no por esto buscó un equilibrio presupuestal a toda costa. El crédito externo fluyó a México y a Carrillo Flores le dió el margen que necesitaba para maniobrar. Entre 1952 y 1958 la economía creció a una tasa anual de 6.4\%, el ingreso por habitante aumentó más del $20 \%$ durante el sexenio y el ingreso nacional que resultó sobresaliente se redistribuyó entre las familias de menores ingresos.

Carrillo Flores aconsejó la devaluación de 1954, la del sábado de gloria, que llevó el tipo de cambio al añorado $\$ 12.50$ por dólar. Durante 22 años se sostuvo ese tipo de cambio, el cual, al fijarse, provocó sobresalto, revuelo y acervas críticas contra el secretario de Hacienda. Se le reprochó el monto de la devaluación, que parecía excesivo y el momento, que parecía imprudente. Muchas semanas santas después se siguió especulando con la compra de dólares. La permanencia de la estabilidad acabó con las críticas, naturalmente.

En 1958 Don Antonio inició su segunda etapa en su ya ilustre carrera al servicio de la nación. El foro: las relaciones internacionales. Su actuación en la diplomacia tuvo como constantes el Derecho como arma y los derechos de México como principio. Siempre usó el primero para defender los segundos y con esto dio vigencia y realce a la famosa frase de Juárez: "El respeto al derecho ajeno es la paz".

Carrillo Flores tuvo a su cargo las embajadas de México en los Estados Unidos y en la Unión Soviética. Raro privilegio. Su experiencia directa con la diplomacia de las dos superpotencias confirmó su idea de que la negociación de los conflictos es el camino siempre necesario y siempre posible.

Antes y después de que Don Antonio estuviera en la embajada de México en la URSS, desempeñó diversas actividades, y en todas 
dejó un huella: dirigió el Fondo de Cultura Económica, presidió la Primera conferencia mundial sobre población, fue diputado federal, dictó excelentes cátedras en El Colegio Nacional, del que fue miembro, y aceptó la ingrata tarea de dirigir uno de los grandes bancos de México, justo después de la nacionalización de la banca.

Profundo conocedor de la Constitución y de nuestra historia, en múltiples ocasiones abordó con lucidez la cuestión del Estado y los particulares. Al tomar posesión de su cargo como Rector del ITAM habló sobre esc tema a propósito de la educación superior. A continuación cito in extenso el discurso que pronunció en aquella ocasión:

Cuando se trata de la educación superior es natural, es imprescindible conjugar la actividad pública con la privada. La idea no es nueva. Nuestra Constitución, obra del Congreso Revolucionario de 1917, que introdujo reformas muy profundas en nuestra vida social, que proclamó antes que ninguna la Reforma Agraria, los derechos de los trabajadores y la soberanía de la Nación sobre sus recursos básicos, todo lo cual extendió la órbita de las atribuciones estatales, contenia en su texto inicial un precepto que, tal vez por su corta vigencia, no es frecuente citar: el Gobierno Federal estaba facultado para crear escuelas profesionales y demás instituciones concernientes a la cultura superior general de los habitantes de la República sólo entre tanto que dichos establecimientos pudieran sostenerse por la iniciativa de los particulares.

En 1921, al renacer con un nuevo espíritu la Secretaría de Educación Pública, el presidente Obregón y el insigne José Vasconcelos pensaron, con razón, que el estado mexicano tenía responsabilidades permanentes y no transitorias en un área tan vital y obtuvieron que se eliminara la última frase del párrafo citado.

Esta reforma no significó, sin embargo, que el presidente Obregón, como ninguno de sus asesores, todos ellos de un sano y patriótico realismo, llegaran al otro extremo, que habría sido suicida, de excluir a los particulares de la educación superior. En ese campo México reclama la aportación de todos sus hijos, en ideas, en inquietudes. Aparte de que, aunque no sea ésta la razón decisiva para justificar la existencia de las instituciones privadas universitarias y tecnológicas, es un dato evidente que los recursos de los erarios nacionales y locales han sido y son escasos frente a la magnitud de las necesidades que deben atender; tanto más que desde hace casi medio siglo, a los servicios que confiaban al Estado las concesiones del liberalismo clásico, se sumó la ingente tarea de levantar la infraestructura que hiciese posible la modernización y el desarrollo de nuestras comunidades rurales y urbanas.

Que la conjugación de esfuerzos se reconociera como indispensable no significa que haya sido siempre sencilla. Pero ello no debe extrañarnos. Muy pocas cosas han sido sencillas en este largo batallar de México por afirmar su identidad, modelar sus instituciones conforme a su propio 
estilo y conquistar niveles mejores de vida para su pueblo. Lo cierto es que desde fines del régimen del presidente Cárdenas, en 1940, quedó definido, en una ley en sentido material, el estatuto de los establecimientos privados que aspirasen a colaborar con el Estado Federal en la prestación del servicio público a formar profesionales, maestros e investigadores. Y que en la ley orgánica de la Educación Pública promovida por el presidente Avila Camacho se incluyó un texto conforme al cual, el estado procurará fomentar por medio de universidades o de instituciones particulares, la educación superior profesional... ${ }^{1}$

Al decidirse a dirigir una universidad particular, Carrillo flores no abandonó su vocación de servicio público. Para él, la ampliación de la educación superior y la formación integral del universitario eran factores esenciales para el desarrollo del país:

México se halla en el umbral de un austero, valeroso proceso de reexamen de sistemas y de métodos, que se efectúa en el marco de nuestros ideales perennes de libertad, de justicia social y de progreso. Este reexamen tiene a la educación superior como uno de sus objetivos indeclinables.

Sabemos que la magna, la permanente tarea de promover el progreso nacional sin sacrificio de nuestra independencia exige formar técnicos e investigadores en muchas ramas nuevas, cuyo número aumenta día con día.

Hay que seguir fomentando que las universidades enseñen tecnologias y los institutos técnicos humanidades. ${ }^{2}$

Hacia el final de su vida, en la Conferencia "Política y humanismo" que dictó el 13 de mayo en el ITAM, Don Antonio Carrillo Flores dijo:

...una política humanista es aquélla en que el Estado, los partidos politicos y los ciudadanos, cuidan;

a) de eliminar todas las formas de acción estatal arbitraria, violatoria de los derechos susceptibles de protección;

b) de promover el progreso equilibrado, económico y social, para hacer posible que los nuevos derechos incorporados en la Constitución, pasen del mundo de lo ideal al de la realidad;

c) de, cosa muy dificil, aunque menos en México que en otros países, tratar a sus semejantes como iguales, independientemente de su posición social. No hablar de tú a quien no pueda contestar de tú; y

d) de defender la identidad de México como Nación y su soberanía como Estado. ${ }^{3}$

En verdad Don Antonio Carrillo Flores fue un "político humanista".

1 Revisu del ITAM, número 1, México, verano de 1973, p. 24.

2 Revista del ITAM, número 1, México, verano de 1973, p. 25.

3 Estudios, número 3, México, otoño de 1985, pp. 124-125. 